УДК 373.5.016:[811.111(07):028]

DOI: $10.35619 /$ iiu.v1i11.274

\author{
Olha Bezkorovaina \\ Doctor of Pedagogic Sciences, \\ Full Professor, Head at the Department \\ of Foreign Language Teaching Methodology \\ Rivne State University for the Humanities, \\ Rivne, Ukraine \\ ORCID: 0000-0001-7144-9946, \\ e-mail: olg2686@gmail.com \\ Yulia Kolibek \\ Student at the Foreign Language Faculty, \\ Rivne State University for the Humanities \\ Rivne, Ukraine \\ ORCID: 0000-0002-2721-0927, \\ e-mail:yuliakolibek@gmail.com
}

\title{
READING AS A SUBJECT OF SCIENTIFIC RESEARCH
}

\begin{abstract}
The article is devoted to the problem of the formation of foreign language competence in reading for pupils of secondary school. The general characteristics of competence in foreign language reading comprehension are given. The aims of its formation at school were defined. The components of reading comprehension competence namely: skills, habits, knowledge and communicative ability. Stages of reading comprehension competence formation were given.

The article analyzes the problem of forming foreign language competence in reading. Properly formed foreign language competence in reading helps to work with textbooks and other educational means, contributes to the expansion of the pupils' scientific knowledge and to the skills formation of independent cognitive activity. The properly formed skills of foreign language competence in reading also allow learners to expand and deepen their knowledge.

In the article it is shown that the formation of foreign language competence of reading involves the acquisition of knowledge by learners, the formation of skills and development of reading skills, as well as the improvement of psychophysiological mechanisms of reading. It was proved that reading is one of the most important factors in assessing a learner's linguistic competence. Moreover, it was proved that the ability to read allows pupils to use literature in a foreign language to find information on the specialty and to improve the skills of oral speech.

For solving the problems were used the following methods, namely general scientific methods of theoretical and empirical research. In addition, methods of comparison and generalization of facts analysis of psychological and pedagogical literature were used at the stage of theoretical research.
\end{abstract}

Keywords: foreign reading competence, stages of reading, types of reading, reading techniques, scanning, skimming, intensive reading, extensive reading, reading skills.

Problem statement. The formation of foreign language competence of reading is determined by the need to study it in the context of the competence approach. It is necessary to determine the structure of foreign language competence of reading, clarify 
the goals of its formation in secondary school, outline the stages of formation of foreign language competence of reading.

Research publications. Despite the fact that many scientists, namely M. Z. Biboletova, J. M. Berman, S. V. Haponova, Z. I. Klichnikov, E. V. Musnitska, $\mathrm{K}$. I. Onishchenko were engaged in the method of formation of foreign language competence in reading. The problem cannot be considered finally solved, as the characteristics of foreign language competence of reading, the purposes of its formation in pupils of secondary school and the stages of formation of competence in reading need to be clarified.

Thus, the research aim and objective is to characterize the method of forming foreign language competence of reading, taking into account modern conditions and trends; the purpose of its formation in pupils.

Presenting the main research material. Reading is a process of receptive the language. It is the process of recognition, interpretation, and perception of written or printed materials. Reading proficiency plays a very significant role in understanding a written statement accurately and efficiently.

In English language teaching, reading is one of the most important factors in assessing a learner's linguistic competence. Indeed, even the researcher Brown claims that the teaching of reading has been an essential part of learning a language ever since foreign language began to be taught (Brown, 2001, p.165).

Reading helps in the mental development and is known to stimulate the developing of the muscles of the eyes. Reading is an activity that involves greater levels of concentration and adds to the conversational skills of the reader. It is an indulgence that enhances the knowledge acquired, consistently. «The habit of reading also helps readers to decipher new words and phrases that they come across in everyday conversations» Grellet (2001, p.8).

Reading is a receptive type of speech activity aimed at the perception and understanding of a written text. Reading is a component of human communication, as it provides a written form of communication. Psychophysiological components of reading are visual perception, internal speech, text segmentation, anticipation (or probable prediction), long-term memory and comprehension.

The psychophysiological basis of reading is the operation of visual perception of the text and its comprehension. When reading information enters the reader through the visual channel, so the crucial role is played by visual sensations. Due to this, reading is accompanied by inner speech, which becomes full, extended speech when reading aloud.

A person who reads silently about himself must hear what he is reading, so auditory sensations are also a mandatory element of reading. These feelings make it possible to control the correctness of one's own reading, but they do not play a dominant role, but in the same way, they are subordinated to the above feelings.

Reading as a type of receptive activity, namely listening is based on the recognition of language units of written text. Depending on the strength of language acquisition and the level of formation of the mechanisms of visual perception, the process of recognition can be carried out quickly and directly, or at a slow pace with elements of recollection. From a psychological point of view, the process of perceiving and understanding a text is directly related to comprehension and memory. Perceiving the text, the reader identifies the individual links that are most important to him, and synthesizes these links into a single whole. Indeed, operational and long-term memory helps thinking. Perception of information and its comprehension by a mature reader is carried out simultaneously. These components of the reading process are inextricably linked, namely the quality of 
perception depends on the nature and level of understanding of the text, its completeness, depth and accuracy.

Reading competence is the ability to read authentic texts of different genres and types with different levels of understanding of the content in terms of indirect communication. The components of reading competence are skills, abilities, knowledge, as well as communication skills, namely - reading skills. Skills of reading competence include speech, learning, intellectual, organizational and compensatory skills.

Among the speech skills of reading are determined following:

- $\quad$ ability to find basic information in the text and predict its content;

- $\quad$ ability to choose the main facts without paying attention to the secondary ones;

- $\quad$ ability to selectively understand the necessary information of pragmatic texts based on linguistic guess, context;

- ability to ignore unknown language material that is irrelevant to comprehension, etc.

The effectiveness of the formation of reading competence depends on the level of formation of students' intellectual skills, such as: probable prediction, critical evaluation of reading, combination in the process of visual perception of mnemonic and logicalsemantic activity, classification and systematization of information.

The success of the formation of reading competence depends on various factors: individual age characteristics of students; the presence or absence of motives for learning in general and reading foreign language in particular; the development of attention and interest; the level of students' ability to apply reading strategies; the ability to rely on previous speech experience; ability to use experience and speech skills in the native language.

Factors that affect reading success can be grouped into the following groups:

1) conditions of perception of writing texts;

2) individual psychological features the reader himself;

3) linguistic characteristics of the text.

In the process of forming the foreign reading competence, there may be difficulties related to the content of the text:

- $\quad$ understanding the subject content (facts);

- $\quad$ understanding the logic of presentation;

- $\quad$ understanding of the general idea, motives, actions of actors.

The affiliation of a text to a certain genre and the presence of appropriate features of the genre cause a new group of difficulties associated with the genre of the text.

According to the difficulties that arise, the goals of teaching a foreign language are formed.

The program of the foreign language for schools states that graduates should read and understand texts on modern topics about the lives of adolescents, newspaper articles about events in the world and in our country. In addition, they should understand the expressions of wishes and feelings in personal letters and be able to find and remove the necessary information describing events in newspaper or magazine articles and brochures. The volume of texts for reading in the $11^{\text {th }}$ grade should be not less than 1900 printed units. According to the Common European Framework of Reference for Languages, secondary school students, namely $10^{\text {th }}$ and $11^{\text {th }}$ grades continue to master reading competence to achieve level B1 (standard level), level B1 (academic level) or level B2 (level of philological profile training).

In the process of formation of reading competence, educational, developmental and upbringing goals are also realized, which are subordinated to the practical goal. 
The educational goal involves students acquiring a variety of knowledge and obtaining cognitive information from texts, as well as the formation of students' learning skills and reading strategies.

The developmental goal involves the development of students' cognitive processes involved in reading - attention, auditory perception, different types of visual memory, thinking, imagination. The educational goal involves educating students in the culture of reading, as well as emotional and value attitudes to what is read.

The goals are realized comprehensively, which contributes to the diverse personal activity of the student. The formation of reading competence involves teaching students of different types of it.

Douglas discusses that students should be trained to be flexible in reading by using different kinds of exercises such scanning, skimming, and critical reading (Brown, 2001, p. 127). Reading is very important to our studying English, especially reading speed, skills, factors and steps. So we should master some good reading skills to improve our English levels.

The four main types of reading techniques are the following: scanning, skimming, intensive reading, extensive reading.

Scanning is a useful skill to locate a specific item of information that we need, such as a date, a figure, a name, a date, a symbol, a formula, or a phrase. In scanning we focus our search only on the information we want, passing quickly other all the irrelevant material. Scanning involves quick eye movements, not necessarily linear in fashion, in which the eyes wander until the reader finds the piece of information needed. The reader knows what the item looks like and so, knows when he has located what he had been searching for. It is assumed, then, that very little information is processed into long-term memory or even for immediate understanding because the objective is simply matching.

Skimming is the technique we generally use to determine whether a book or an article merits a more careful and thorough reading. Skimming may sometimes be the prerequisite of reading for full understanding. The difference between scanning and skimming is that in skimming we are not locating specific, isolated and scattered items of information what we are trying to get is the general, overall ideas of the whole text. Therefore, the key to skimming is to know where to find the main ideas of different paragraphs and to be able to synthesize them into an organic whole by way of generalization. Skimming is a quick reading to get to know the general meaning of a passage, how the passage is organized, an idea of the intention of the writer.

Skimming is a more complex task than scanning because it requires the reader to organize and remember some of the information given by the author, not just to locate it. Skimming involves a thorough overview of a text and implies a reading competence. Scanning is more a limited activity, only retrieving information relevant to a purpose.

Often skimming and scanning are used together when pupils are reading the text. For instance, the reader may skim through first to see if it is worth reading, then read it more carefully and scan for a specific piece of information to note. By practicing skimming and scanning, the individual learns to read and select specific information without focusing on information that is not important for meaning. Brown (2001, p.283) suggested that «perhaps the two most valuable reading strategies for learners as well as native speakers are skimming and scanning».

Intensive reading involves learners reading in detail with specific learning aims and tasks. This type of reading has indeed beneficial to language learners as it helps them understand vocabulary by deducing the meaning of words in context. Moreover, it helps with retention of information for long periods of time and knowledge resulting from intensive reading persists in your long-term memory. In intensive reading, readers extract 
specific information in shorter texts. Brown (2001, p.136) resembles intensive reading to a zoom lens strategy and states that «intensive reading calls attention to grammatical forms, discourse markers and other surface structure details for the purpose of understanding literal meaning, implications, rhetorical relationships»».

Sometimes intensive reading is called «Narrow Reading». It may involve the students reading selections by the same author or several texts about the same topic. When this happens, the content and grammatical structures repeat themselves and the students get many opportunities to understand the meaning of the text. The aim of «Narrow Reading» targets on improving reading comprehension. It is based on the premise that the more familiar the reader is with the text either due to the subject matter or reading the other works of the same author, the more comprehension is promoted.

Extensive reading involves reading for pleasure. Because there is an element of enjoyment in extensive reading it is unlikely that students will undertake the extensive reading of a text they do not like. Grellet (2001, p.216) identifies extensive reading as «occurring when students read large amounts of high-interest material, usually out of class, concentrating on meaning, «reading for gist» and skipping unknown words».

Therefore, skimming, scanning, intensive reading and extensive one are sometimes referred to as types of reading and at the same times, they are known as skills. By the way of reading, a learner can master these high-tech and cultural knowledge concerning English-speaking countries. As reading is the only time-saved way to absorb foreign advanced technology, by reading, we can learn more and make contributions to the construction of our motherland. In that case, reading becomes necessary and urgent because Reading can help absorb all kinds of information. Reading English books, magazines can improve reading ability step by step, speeding up cultivating and forming good reading habits.

Conclusions and further research prospects. Thus, reading can help learners develop their interest. By reading a lot, one can advance their English background knowledge and broaden his or her vision, inspire his thought, build the values, train the creative performance and develop his intelligence. The psycholinguistic view's goals of teaching reading are to train students to form their expectation for a reading activity, to encourage students to take risks in guessing, in ignoring the fact that they should always be correct, and to train pupils to use the minimum number of syntactic and semantic clues to obtain the maximum amount of information. Properly formed foreign language competence in reading helps pupils to work with textbooks and other educational books, contributes to the expansion of the students' scientific knowledge and to the skills formation of independent cognitive activity.

\section{СПИСОК ВИКОРИСТАНИХ ДЖЕРЕЛ}

Brown H. Douglas. (2001). Teaching by principles an interactive approach to language pedagogy (second edition). Addisont Wesley Longman, Inc., 350 p.

Grellet, F. (2001). Developing reading skills. Beijing: Foreign language teaching and Research press - Cambridge: Cambridge University Press, 137 p.

Борецька, Г. (2012). Методика формування іншомовної компетентності у техніці читання. Іноземні мови, 1, сс. 3-8.

Безкоровайна, О.В., Багнюк К.Р. (2015). Вивчення іноземної мови за допомогою сучасних інформаційних технологій (інтернет-ресурсів) у навчально-виховній діяльності учнів старших класів. Оновлення змісту, форм та методів навчання $i$ виховання в закладах освіти: науковий збірник: наукові записки РДГУ. Випуск11(54). С. 72-75. 
Безкоровайна, О.В. (2016). Інноваційна діяльність викладача іноземної мови: проблеми, теорії та практики. Оновлення змісту, форм та методів навчання $i$ виховання в закладах освіти: науковий збірник: наукові записки РДГУ. Випуск14(57). С. 50-60.

Колібек Юлія, Безкоровайна Ольга (2020). Формування іншомовної компетентності учнів старшої школи в процесі вивчення іноземної мови : матеріали I Міжнародної науково- практичної інтернет-конференції (30 квітня 2020 року) : збірник тез. Бердянськ: БДПУ. С. 183-187.

Безкоровайна, О. В. та Петрівський, Я. Б. (2018). Інноваційні підходи до організації методичної підготовки майбутнього вчителя англійської мови (на прикладі спільного проекту Британської Ради в Україні та Міністерства освіти і науки України «Шкільний вчитель нового покоління»). Нова педагогічна думка. №4. C. 96-99.

Harvey S. \& Goudvis A. (2010). Strategies that work teaching comprehension to enhance understanding. York, ME: Stenhouse Publishers, $120 \mathrm{p}$.

\section{REFERENCES}

Brown H. Douglas. (2001). Teaching by principles an interactive approach to language pedagogy (second edition). Addisont Wesley Longman, Inc., $350 \mathrm{p}$.

Grellet, F. (2001). Developing reading skills. Beijing: Foreign language teaching and Research press - Cambridge: Cambridge University Press, 137 p.

Boretska, H. (2012). Metodyka formuvannia inshomovnoi kompetentnosti u tekhnitsi chytannia [Methods of Formation of the Foreign Language in the Reading Technique]. Inozemni movy, 1. s. 3-8.

Bezkorovaina, O. \& Bagniuk, K. (2015). Vyvchennia inozemnoï movy za dopomohoiu suchasnykh informatsiinykh tekhnolohii (internet-resursiv) u navchalnovykhovnii diialnosti uchniv starshykh klasiv [Learning a Foreign Language by Means of Modern Information Technologies (Internet resources) in the Educational Activities of High School Students]. Onovlennya zmistu. form ta metodiv navchannya $i$ vikhovannya $v$ zakladakh osviti:naukoviy zbirnik : naukovi zapysky RDHU. Vypusk11(54). S. 72-75.

Bezkorovaina, O. (2016). Innovatsiina diialnist vykladacha inozemnoi movy: problemy, teoriï ta praktyky [Innovative Activity of a Foreign Language Teacher: Problems, Theories and Practices]. Onovlennia zmistu. form ta metodiv navchannia $i$ vykhovannia $v$ zakladakh osviti: naukoviy zbirnyk: naukovi zapiski RDGU. Vipusk14(57). S. 50-60.

Kolibek, Yu \& Bezkorovaina. O. (2020). Formuvannia inshomovnoi kompetentnosti uchniv starshoi shkoly v protsesi vyvchennia inozemnoi movy [Formation of Foreign Language Competence of High School Students in the Process of Learning a Foreign Language] : materialy Ist Mizhnarodnoi naukovo-praktychnoi internet-konferentsii (30 kvitnia 2020 roku): zbirnyk tez. Berdiansk: BDPU. C. 183-187.

Bezkorovaina, O. \&. Petrivskyi Ya. (2018). Innovatsiini pidkhody do organizatsii metodychnoi pidhotovky maibutnoho vchytelia anhliiskoi movy (na prykladi spilnoho proiektu Brytanskoi Radi v Ukraini ta Ministerstva osviti i nauki Ukrainy "Shkilnii vchytel novoho pokolinnia") [Innovative Approaches to the Organization of Methodical Training of Future English Teachers (on the example of a joint project of the British Council in Ukraine and the Ministry of Education and Science of Ukraine «School teacher of the new generation")] Nova pedahohichna dumka. No 4 . S. 96-99.

Harvey S. \& Goudvis A. (2010). Strategies that Work Teaching Comprehension to Enhance Understanding. York, ME: Stenhouse Publishers, 120 p. 
Інноватика у вихованні. Випуск 11. Том 1. 2020.

ЧИТАННЯ ЯК ПРЕДМЕТ НАУКОВОГО ДОСЛІДЖЕННЯ

Безкоровайна Ольга

доктор педагогічних наук, професор,

завідувачка кафедри методики

викладання іноземних мов

факультету іноземної філології

Рівненського державного гуманітарного

Університету

м. Рівне, Україна

ORCID: 0000-0001-7144-9946, e-mail:olg2686@gmail.com

Юлія Колібек

студентка факультету іноземної філології

Рівненського державного гуманітарного

Університету

м. Рівне, Україна

ORCID: 0000-0002-2721-0927,

e-mail: yuliakolibek@gmail.com

Анотація. Стаття присвячена проблемі формування іншомовної читацької компетентності. Представлено загальну характеристику читацької компетентності іноземною мовою. Визначено цілі іï формування в закладах освіти. Схарактеризовані компоненти компетенції розуміння читання: вміння, навички, знання та комунікативна здатність. Представлено етапи формування компетентності з розуміння читання.

Досліджено загальну характеристику компетентності читання іноземною мовою; описано формування компетенції читання та його цілі. Мотивом читання як комунікативної діяльності є спілкування, а метою - отримання необхідної інформації, причому робота з текстом може переслідувати різні цілі: іноді потрібно лише визначити, про що цей текст, в інших випадках важливо зрозуміти основну або нову інформацію, задум автора, підтекст. Сформована іншомовна компетенція в читанні допомагає у роботі підручником й іншими навчально-методичними посібниками, сприяє розширенню наукових знань

Здійснено характеристику чотирьох основних типів техніки читання, а саме: сканування, скімінгу, інтенсивного читання, розширеного читання. Доведено, що для повного й точного розуміння інформації, викладеної у тексті, учень повинен володіти значним запасом лексичних одиниць, мати глибокі знання з граматики i достатню практику в читанні текстів різних жанрів. Сформовані навички іншомовної компетенції в читанні дозволяють користуватися іншомовними джерелами для пошуку інформації та вдосконалювати навички усного мовлення, а також самостійно розширювати і поглиблювати наукові знання.

Для реалізації поставленої мети дослідження використовувались загальнонаукові методи теоретичних та емпіричних досліджень, а також методи порівняння та узагальнення аналізу фактів психолого-педагогічної літератури.

Ключові слова: компетентність, етапи читання, види читання, техніки читання, сканування, скімінг, інтенсивне читання, розширене читання, навички читання.

Стаття надійила до редакиії 10.05. 2020 p. 